\title{
Understanding Job Transitions and Retirement Expectations Using Stated Preferences for Job Characteristics
}

Nicole Maestas, Kathleen J. Mullen, David Powell, Till von Wachter, and Jeffrey Wenger

Project \#: R-UM17-08 


\title{
Understanding Job Transitions and Retirement Expectations Using Stated Preferences for Job Characteristics
}

\author{
Nicole Maestas \\ Harvard University and NBER \\ Kathleen J. Mullen \\ RAND \\ David Powell \\ RAND \\ Till von Wachter \\ University of California Los Angeles and NBER \\ Jeffrey Wenger \\ RAND
}

February 2019

\author{
Michigan Retirement Research Center \\ University of Michigan \\ P.O. Box 1248 \\ Ann Arbor, MI 48104 \\ www.mrrc.isr.umich.edu
}

(734) 615-0422

\section{Acknowledgements}

The research reported herein was performed pursuant to a grant from the U.S. Social Security Administration (SSA) funded as part of the Retirement Research Consortium through the University of Michigan Retirement Research Center Award RRC08098401-09. The opinions and conclusions expressed are solely those of the author(s) and do not represent the opinions or policy of SSA or any agency of the federal government. Neither the United States government nor any agency thereof, nor any of their employees, makes any warranty, express or implied, or assumes any legal liability or responsibility for the accuracy, completeness, or usefulness of the contents of this report. Reference herein to any specific commercial product, process or service by trade name, trademark, manufacturer, or otherwise does not necessarily constitute or imply endorsement, recommendation or favoring by the United States government or any agency thereof.

\section{Regents of the University of Michigan}

Jordan B. Acker; Huntington Woods; Michael J. Behm, Grand Blanc; Mark J. Bernstein, Ann Arbor; Paul W. Brown, Ann Arbor; Shauna Ryder Diggs, Grosse Pointe; Denise Ilitch, Bingham Farms; Ron Weiser, Ann Arbor; Katherine E. White, Ann Arbor; Mark S. Schlissel, ex officio 


\title{
Understanding Job Transitions and Retirement Expectations Using Stated Preferences for Job Characteristics
}

\begin{abstract}
As the population ages in the United States and other countries, encouraging older individuals to work would help counter increasing dependency ratios and improve national economic outcomes. Extending working lives is likely not simply a function of improving monetary incentives. Instead, job characteristics are also potentially important, yet understudied, determinants of whether individuals near retirement remain in the labor force. We use previously-collected data on job characteristics and preferences for job characteristics and work at older ages from the 2015 American Working Conditions Survey. We match the 2015 data with new data on job transitions collected three years after the initial survey. We use the matched data to study the relationship between preferences for job characteristics and actual job transitions. We then estimate heterogeneity in preferences for job characteristics as a function of age and plans for retirement. We test whether preferences differ for older workers ages 50 to 61 with different self-perceived probabilities of working in the future. Finally, we test whether preferences differ for retirement-aged individuals ages 62 and older who are working or not working.
\end{abstract}

\section{Citation}

Maestas, Nicole, Kathleen J. Mullen, David Powell, Till von Wachter, and Jeffrey Wenger. 2019. "Understanding Job Transitions and Retirement Expectations Using Stated Preferences for Job Characteristics." Ann Arbor MI: University of Michigan Retirement Research Center (MRRC) Working Paper, WP 2019-396.

https://mrdrc.isr.umich.edu/publications/papers/pdf/wp396.pdf

\section{Authors' acknowledgements}

We thank David Zingher for excellent research assistance. Corresponding author: dpowell@rand.org. 


\section{Introduction}

As the population ages in the United States and other countries, encouraging older individuals to work would help counter increasing dependency ratios and improve national economic outcomes. A fuller understanding of retirement transitions and the types of jobs that incentivize older individuals to remain in the workforce would help inform such encouragement. Extending working lives is likely not simply a function of improving monetary incentives. Instead, job characteristics are also potentially important, yet under-studied, determinants of whether individuals near retirement remain in the labor force. This paper aims to address this research gap by collecting and analyzing information about working conditions and stated preferences for working conditions for a nationally representative sample of American workers.

We use previously-collected data on both job characteristics and preferences for job characteristics and work at older ages from the 2015 American Working Conditions Survey (AWCS). To the 2015 data, we match information on job transitions three years after the initial survey. We use the matched data to study the relationship between preferences for job characteristics and actual job transitions. We then estimate heterogeneity in preferences for job characteristics as a function of age and plans for retirement. We test whether preferences differ for older workers ages 50 to 61 with different self-perceived probabilities of working in the future. Finally, we test whether preferences differ for retirement-aged individuals ages 62 and older who are working or not working.

We find support for the hypothesis that, in general, workers transition to jobs with characteristics that align with their preferences for those characteristics. Workers who switch away from having certain attributes tend to value to those attributes less than those who remain in jobs with the same attributes. Similarly, workers who switch to jobs with certain attributes tend to value those attributes more than those who remain in jobs without the same attributes. We are not able to 
draw strong conclusions about differences between those who exit employment with certain attributes versus those who remain in jobs without certain attributes.

Narrowing in on older workers specifically, among those ages 50 to 61, we find weak evidence that workers who have lower expectations of working at age 62 tend to value nonwage job characteristics more than those who have higher expectations of working at age 62 . However, we do not find any differences between individuals ages 62 and older who are working versus not working.

\section{Data and methodology}

The data for in this paper come from two waves of the American Working Conditions Survey (AWCS). The first wave, conducted in 2015, consists of two modules: a comprehensive survey of the prevalence of various working conditions in July and a stated preferences choice experiment in December. The second wave, conducted in 2018, is a refielding of the original July working conditions survey. The AWCS was fielded to a nationally representative (when weighted) sample of Americans ages 18 to 70 in July 2015 who agreed to participate in regular online surveys as part of the RAND American Life Panel (ALP). Respondents who indicate that they do not have a computer at home are provided both a computer and internet access. Since its inception in 2006, the ALP has fielded more than 400 surveys on a wide variety of topics including health, employment, and retirement. All surveys are publicly available and may be linked to one another. We restrict our main sample to the 1,226 probability-based respondents ages 25 to 71 in 2015 who were working in July 2015 and completed all three survey modules. In a secondary analysis, we compare 275 nonworking to 442 working respondents ages 62 and older.

To obtain estimates of Willingness to Pay (WTP) for various job characteristics, we conducted 10 stated preference choice experiments in which we presented to respondents a pair of hypothetical jobs characterized by nine working conditions, their hours per week, and their wages. 
The nine working conditions were: control over hours, paid time off, option to telecommute, pace (relaxed versus fast-paced), independence over work performed, physical demands, working with others (by oneself versus team-based, with and without team-based performance evaluation), opportunities for training, and impact on society. Each experiment varied two nonmonetary features of the jobs (without replacement) and the wage, and respondents were asked whether they preferred Job A or Job B. For more details about the stated preference experiments, see Maestas et al. (2018).

To examine the relationship between stated preferences for working conditions and job transitions from 2015 to 2018, we focus on the six binary working conditions variables and, for each variable, form six groups: A1) those with the desired attribute in both 2015 and 2018, A2) those with the attribute in 2015 and without it in 2018; A3) those with the desired attribute in 2015 and not working in 2018; B1) those without the desired attribute in both 2015 and 2018; B2) those without the attribute in 2015 but with it in 2018; and B3) those without the desired attribute in 2015 and not working in 2018. ${ }^{1}$ Note that a respondent need not change jobs to report a change in working conditions between waves. Table 1 presents the crosswalk between attribute in the stated preference experiment and its definition based on the related question in the main AWCS module for each of the six dimensions of working conditions. See Maestas et al. (2017) for more details about the AWCS survey questions.

Table 2 summarizes the job and employment transitions observed in our sample between 2015 and 2018. For each attribute, we present the unweighted number and weighted percentage of respondents in each group defined above, as well as subtotals of the prevalence of each attribute in 2015. At least two patterns emerge from the raw data. First, there is a strong tendency toward

\footnotetext{
${ }^{1}$ For simplicity we exclude those working conditions with more than two possible values. They are: paid time off (20 paid days per year, 10 paid days per year, or none); physical demands (mostly sitting, moderate physical activity, or heavy physical activity); and working with others (mainly work by yourself, team-based but you are judged by your own performance, or team-based and judged by performance of team).
} 
inertia; for each attribute, more than 60 percent of workers in 2015 have the same attribute in 2018. This makes sense if workers tend to sort themselves into jobs with attributes they value relative to other attributes. Second, for four of the six attributes, we observe that workers are more likely to transition out of employment between waves if they lack the desirable attribute in 2015. Again, preference heterogeneity is likely to play a role in transitions out of employment. That is, exits from employment should be more likely to occur when there is a mismatch between having and valuing a given attribute.

This leads to the two sets of hypotheses that we test in our main sample. First, we hypothesize that workers who remain in jobs with a given attribute tend to value that attribute more than those who transition out of jobs with that attribute - whether to a job without the attribute or out of employment entirely. Second, conversely, we hypothesize that those who transition into jobs with a given attribute (or out of employment) tend to value that attribute more than those who remain in jobs without that attribute. To do this, we estimate WTP for a given attribute using data from the stated preference choice experiments separately for each of the six mutually exclusive groups based on job and employment transitions between 2015 and 2018 and compare them to one another.

Finally, to examine the relationship between stated preferences and retirement expectations, we perform two analyses. First, we estimate WTP for all nine attributes (including nonbinary working conditions) separately by low versus high self-reported probability of working at age 62 for working respondents ages 50 to 61 . We use the unweighted median, 90, to split the sample into low versus high probability older workers. We hypothesize that older workers with a low probability of working at age 62 have higher valuations of nonmonetary attributes on average than same-aged workers with a high probability of working at age 62. Second, we estimate separate models for working versus nonworking respondents ages 62 and older. We hypothesize that "retired" individuals have higher valuations of nonmonetary attributions on average than those working past age 62 . 
Estimating willingness to pay for nonwage attributes

For our main specification, we assume that the underlying choice process can be approximated by a linear indirect utility function:

$$
V_{i j t}=\alpha+X_{i j t}^{\prime} \beta+H_{i j t}^{\prime} \theta+\delta \ln w_{i j t}+\varepsilon_{i j t}
$$

where $V_{i j t}$ represents indirect utility for individual $i$, alternative $j$, for choice pair $t . X_{i j t}$ is the set of nonwage characteristics, $H_{i j t}$ represents a flexible function of hours, and $w_{i j t}$ is the wage.

Assuming that $\varepsilon_{i j t}$ is an Extreme Value Type I random variable, we estimate the probability that an individual selects a job with characteristics $X_{i j t}$, hours $H_{i j t}$, and wages $w_{i j t}$ over a job with characteristics $X_{i k t}$, hours $H_{i k t}$, and wages $w_{i k t}$ with probability

$$
P\left(V_{i j t}>V_{i k t}\right)=\frac{\exp \left[\left(X_{i j t}^{\prime}-X_{i k t}^{\prime}\right) \beta+\left(H_{i j t}^{\prime}-H_{i k t}^{\prime}\right) \theta+\delta\left(\ln w_{i j t}-\ln w_{i k t}\right)\right]}{1+\exp \left[\left(X_{i j t}^{\prime}-X_{i k t}^{\prime}\right) \beta+\left(H_{i j t}^{\prime}-H_{i k t}^{\prime}\right) \theta+\delta\left(\ln w_{i j t}-\ln w_{i k t}\right)\right]} .
$$

Using these parameters, we derive our WTP measure for a particular attribute $r$ as follows.

Consider an individual who is indifferent between not having a particular attribute $r$ at wage $w$, and having the attribute with a corresponding wage decrease equal to $W T P^{r}$ :

$$
\delta \ln w=\beta^{r}+\delta \ln \left[w-W T P^{r}\right]
$$

where $\delta$ and $\beta^{r}$ are the marginal utilities for the log wage and attribute $r$, respectively. Solving for WTP we obtain:

$$
W T P^{r}=w\left[1-e^{\left(\frac{-\beta^{r}}{\delta}\right)}\right]
$$

In the following sections, we present our estimates in terms of $1-e^{\left(\frac{-\beta^{r}}{\delta}\right)}$, such that gaining attribute $r$ is equivalent to a $100\left(1-e^{\left(\frac{-\beta^{r}}{\delta}\right)}\right)$ percent wage increase. We estimate $\delta$ and $\beta^{r}$ separately for workers in each group defined by their transition from 2015 to 2018 for each attribute. See Maestas et al. (2018) for more details about the estimation. 


\section{Joint hypothesis testing}

We test joint significance of the difference in the parameters for the switchers versus nonswitchers and, separately, the exiters versus the nonswitchers. We estimate our logit specification, but fully-interact the six characteristics with indicators based on the six groups defined above, jointly estimating preferences for each group. We perform a one-sided test to determine whether those switching away from a job attribute value it less than those not switching, among those who originally have the amenity. Thus, the null hypothesis is that those switching away from a job attribute value it more than or equal to those not switching. In the case where we study those who originally have the amenity, the hypotheses are denoted by

$$
H_{s}: \beta_{s} \geq 0 \text { versus } H_{s}^{\prime}: \beta_{s}<0 \quad \text { for all } s,
$$

where $s$ denotes one of the parameters of interest. Here the parameters $\beta_{s}$ are the differences in the WTP (defined above) for the attributes for the switchers relative to the nonswitchers. The null hypothesis is that all of these parameters are nonpositive. We follow the approach discussed in Romano and Wolf (2018). The test statistic is represented by

$$
T=\min _{s} \frac{\hat{\beta}_{s}}{\hat{\sigma}_{s}}
$$

The distribution of this test statistic is unknown, but we can simulate it via clustered bootstrap. For $K$ bootstrap samples, we estimate $\tilde{\beta}_{s}^{(k)}$ and $\tilde{\sigma}_{s}^{(k)}$. We study deviations from the parameters estimated using the full sample to simulate the distribution of the test statistic using:

$$
T^{(k)}=\min _{s} \frac{\tilde{\beta}_{s}^{(k)}-\hat{\beta}_{s}}{\tilde{\sigma}_{s}^{(k)}}
$$

The simulated test statistics preserve the dependence across the jointly-estimated parameters. The placement of $T$ in the distribution of $T^{(k)}$ provides a p-value. We use the same null hypotheses when we study workers with an amenity and compare exiters to the nonswitchers. 
The null hypothesis is flipped when we compare the switchers to nonswitchers for the workers who had the amenity in Period 1:

$$
H_{s}: \beta_{s} \leq 0 \text { versus } H_{s}^{\prime}: \beta_{s}>0 \quad \text { for all } s \text {, }
$$

In this case, we replace the "min" with "max" in the test statistic and its simulated values above.

\section{Relationship between stated preferences and job and employment transitions}

Figures 1 to 6 present estimates of WTP for six binary working conditions interacted with dummies for each of six mutually exclusive groups: A1) those with the desired attribute in both 2015 and 2018, A2) those with the attribute in 2015 and without it in 2018; A3) those with the desired attribute in 2015 and not working in 2018; B1) those without the desired attribute in both 2015 and 2018; B2) those without the attribute in 2015 but with it in 2018; and B3) those without the desired attribute in 2015 and not working in 2018. We hypothesize that, among those who start with the desired attribute initially: H1) those who remain in a job with that attribute [group A1] have a higher WTP for the attribute than those who transition to a job without the attribute [group A2]; and H2) those who remain in a job with that attribute [group A1] have a higher WTP for the attribute than those who exit employment [group A3]. Similarly, among those who lack the desired attribute initially: H3) those who remain in a job without that attribute [group B1] have a lower WTP than those who transition to a job with the attribute [group B2]; and H4) those who remain in a job without the attribute [group B1] have a lower WTP than those who exit employment [group B3]. We test each hypothesis separately for each attribute as well as jointly for all attributes (described above).

Table 3 presents the numerical estimates of WTP as well as the results of the individual and joint hypotheses. Generally, because of the small sample sizes in each transition group, we lack power to detect differences at the individual attribute level, though we do find some significant differences. We detect statistically significant differences for nonswitchers and switchers among 
those who originally have the option to telecommute $(0.098$ versus $0.046 ; p<0.05)$, relaxed pace (0.085 versus $0.013 ; \mathrm{p}<0.01)$, and training opportunities $(0.071$ versus $0.020 ; \mathrm{p}<0.05)$. Taken together, we reject the null hypothesis that nonswitchers value the attributes they have in Period 1 less than or the same as those who switch away from those attributes at the 1 percent level $(p=0.005)[H 1]$. We detect a marginally statistically significant difference between nonswitchers and exiters among those who originally have the option to telecommute $(0.046$ versus 0.012 ; $\mathrm{p}<0.1$ ); we are unable to draw strong conclusions about those who exit employment compared to those who remain with a given attribute more generally, however [H2].

Similarly, we reject the null hypothesis that switchers value the attributes they lack in Period 1 more than or the same as those who do not switch toward those attributes at the $10 \%$ level $(p=0.082)[H 3]$. Again, we are unable to draw strong conclusions about those who exit employment compared to those who remain without a given attribute [H4]. Note that, consistent with the idea that individuals sort into jobs with attributes they especially value, we also find that those who originally have an attribute, pooled together, are generally more likely to value that attribute than those who originally lack the attribute $(\mathrm{p}=0.001)$.

\section{Relationship between stated preferences and retirement expectations and outcomes}

Next, we examine the relationship between stated preferences for working conditions and retirement expectations and outcomes. To examine retirement expectations, we restrict our sample to older workers ages 50 to 61 and divide the sample into two groups: those with above- and belowmedian self-reported probability of working at age 62, respectively. The unweighted median probability of working at age 62 is 90 . (We include those who report " 90 " exactly in the abovemedian group.) Figure 7 presents WTP estimates for each job characteristic, including nonbinary attributes. From the figure, it is immediately obvious that older workers who expect to work at age 62 tend to value nonwage job characteristics more than those who do not expect to work at age 62 . 
Table 4 presents numerical estimates and the results of statistical significance tests of equivalent valuations between the two groups separately for each attribute. Unfortunately, given small subsample sizes, the significance tests are generally underpowered. The only attribute whose valuations are statistically significantly different from one another is team-based work where one is evaluated separately versus team-based work where evaluation is based on team performance $(0.119$ versus 0.065 for low- versus high probability individuals, respectively; $\mathrm{p}<0.10$ ). Taken together, low-probability older workers value the sum of nonwage characteristics (i.e., comparing the "best" job with all desirable amenities to the "worst" job with nondesirable amenities) at 63 percent of their current wage, compared with 55 percent among high-probability older workers, though this difference is marginally insignificant $(\mathrm{p}=0.103)$.

Finally, to examine the relationship between stated preferences for job characteristics and retirement outcomes, we restrict our sample to all individuals ages 62 and older and compare valuations of working versus nonworking individuals. The results of this exercise are presented in Figure 8 and the second set of columns in Table 4. In this case, though more attributes have larger valuations among nonworkers than workers, several attributes are valued more by workers than nonworkers (e.g., control over hours, moderate physical activity, independence, and working alone); none of these differences are statistically significant, however. More importantly, taken together elderly nonworkers do not value the full suite of working conditions more than elderly workers (74.7 versus 74.2 percent of their current wage; $p=0.916$ ).

\section{Conclusion}

In this paper, we find support for the hypothesis that, in general, workers transition to jobs with characteristics that more closely align with their preferences. Workers who switch away from having certain attributes tend to value to those attributes less than those who remain in jobs with the same attributes. Similarly, workers who switch to jobs with certain attributes tend to value those 
attributes more than those who remain in jobs without the same attributes. We are not able to draw strong conclusions about differences between those who exit employment with certain attributes versus those who remain in jobs without certain attributes.

Narrowing in on older workers, among those ages 50 to 61 , we find weak evidence that workers who have lower expectations of working at age 62 tend to value nonwage job characteristics more than those who have higher expectations of working at age 62 . However, we do not find any differences between individuals ages 62 and older who are working versus not working. At the same time, our findings are consistent with previous work showing that older workers tend to value nonwage working conditions more than younger workers. In future work, we can examine the relationship between preferences for working conditions and transitions into (and possibly out of) retirement. 


\section{References}

Maestas, Nicole, Kathleen J. Mullen, David Powell, Till von Wachter, and Jeffrey B. Wenger (2017). "The American Working Conditions Survey Data: Codebook and Data Description." RAND Research Tool TL-269-APSF. https://www.rand.org/pubs/tools/TL269.html

Maestas, Nicole, Kathleen J. Mullen, David Powell, Till von Wachter, and Jeffrey Wenger (2018). "The Value of Working Conditions in the United States and Implications for the Structure of Wages." NBER Working Paper 25204.

Romano, J.P. and Wolf, M., 2018, January. Multiple testing of one-sided hypotheses: combining Bonferroni and the bootstrap. In International Conference of the Thailand Econometrics Society (pp. 78-94). Springer, Cham. 


\section{Figure 1. Willingness to pay to set own schedule}

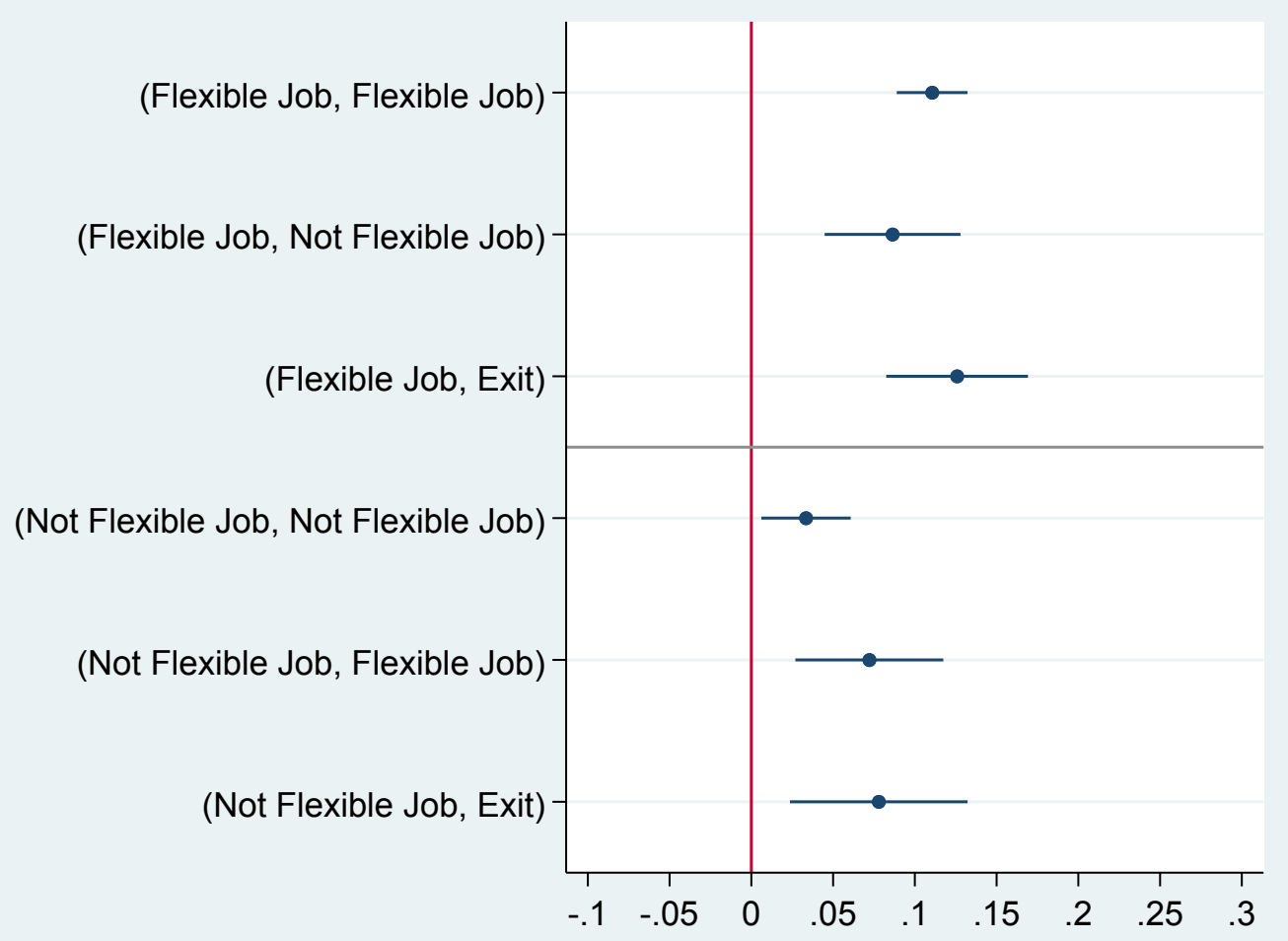


Figure 2. Willingness to pay for option to telecommute

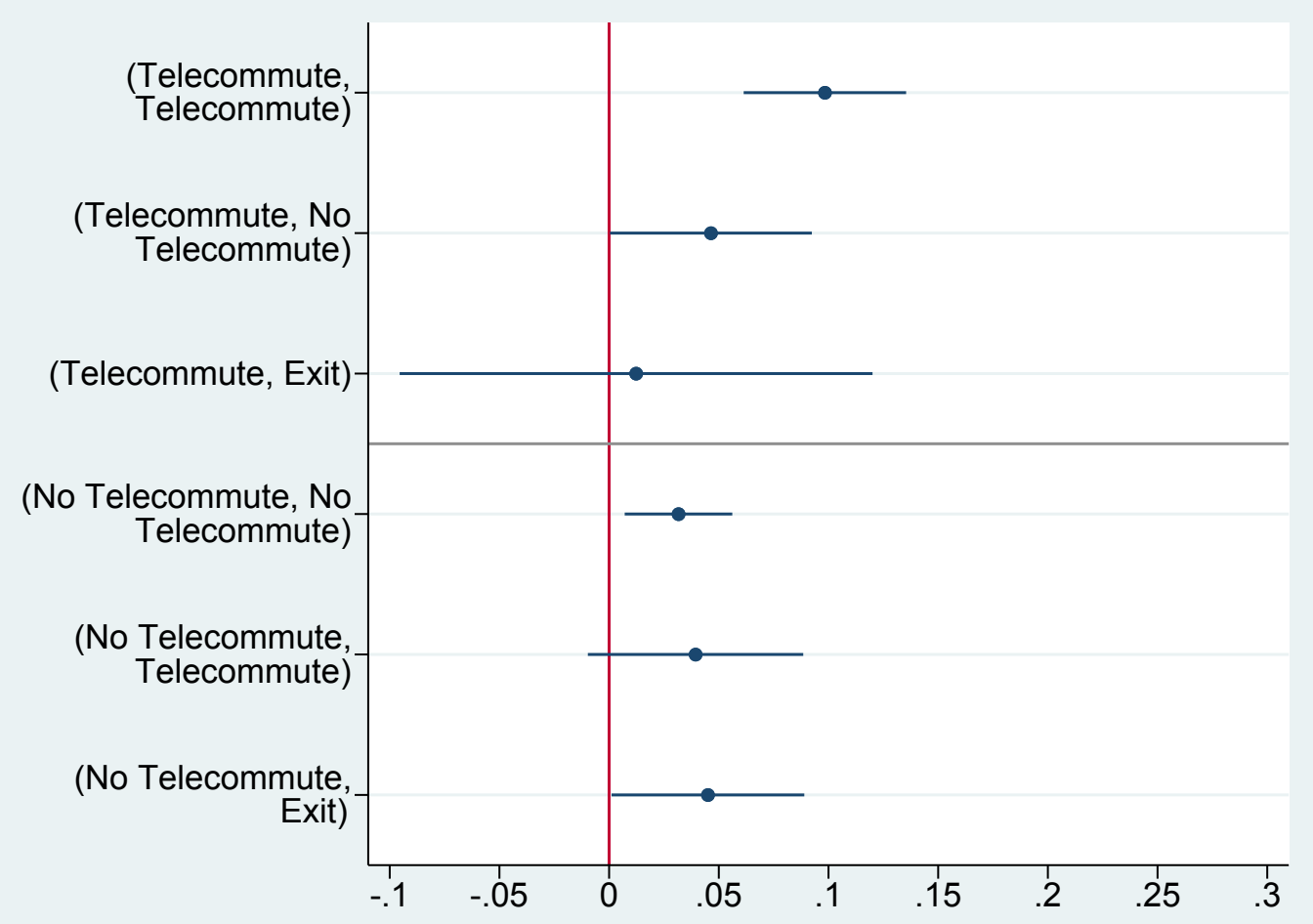


Figure 3. Willingness to pay for relaxed pace

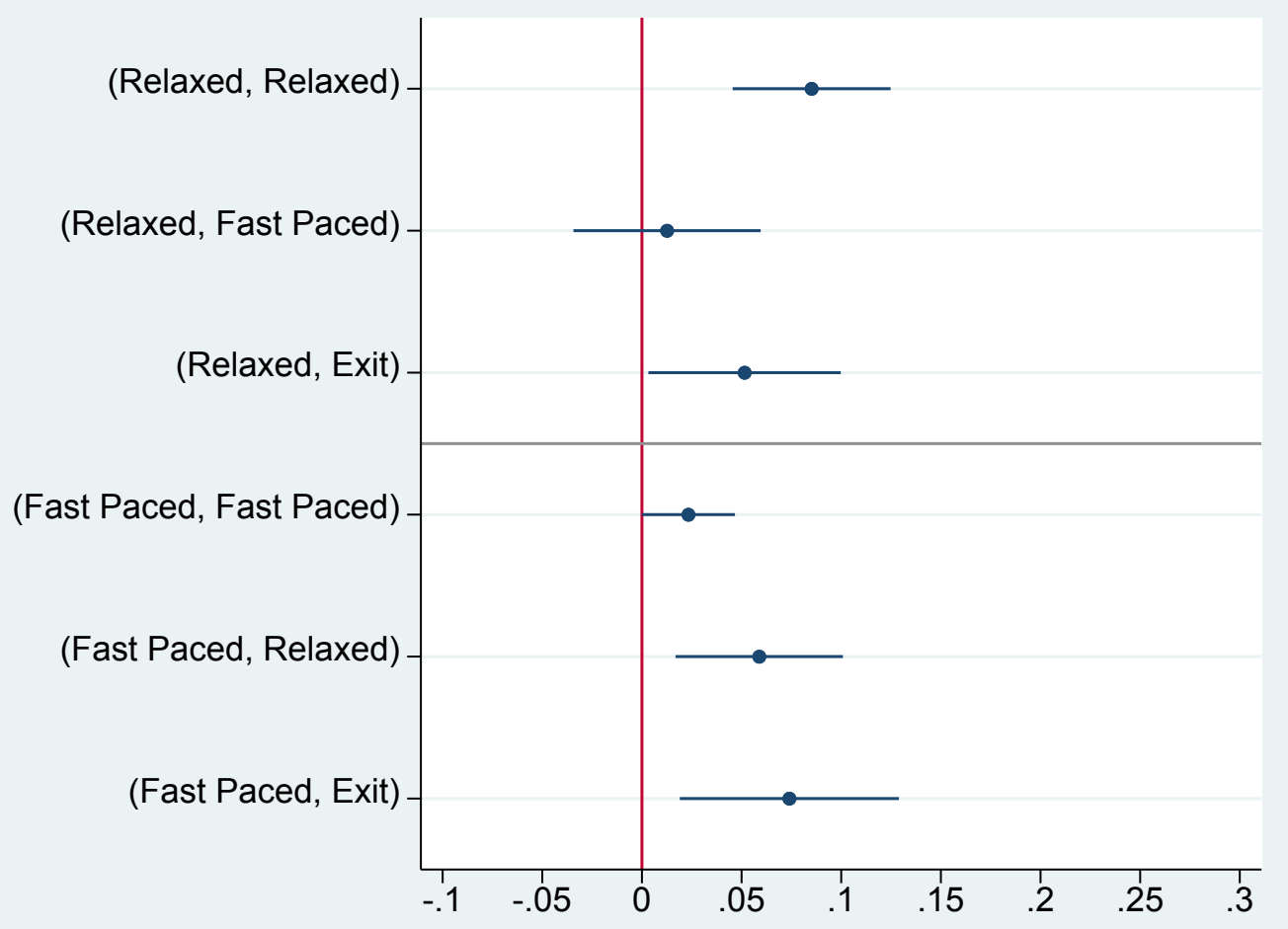


Figure 4. Willingness to pay for independence

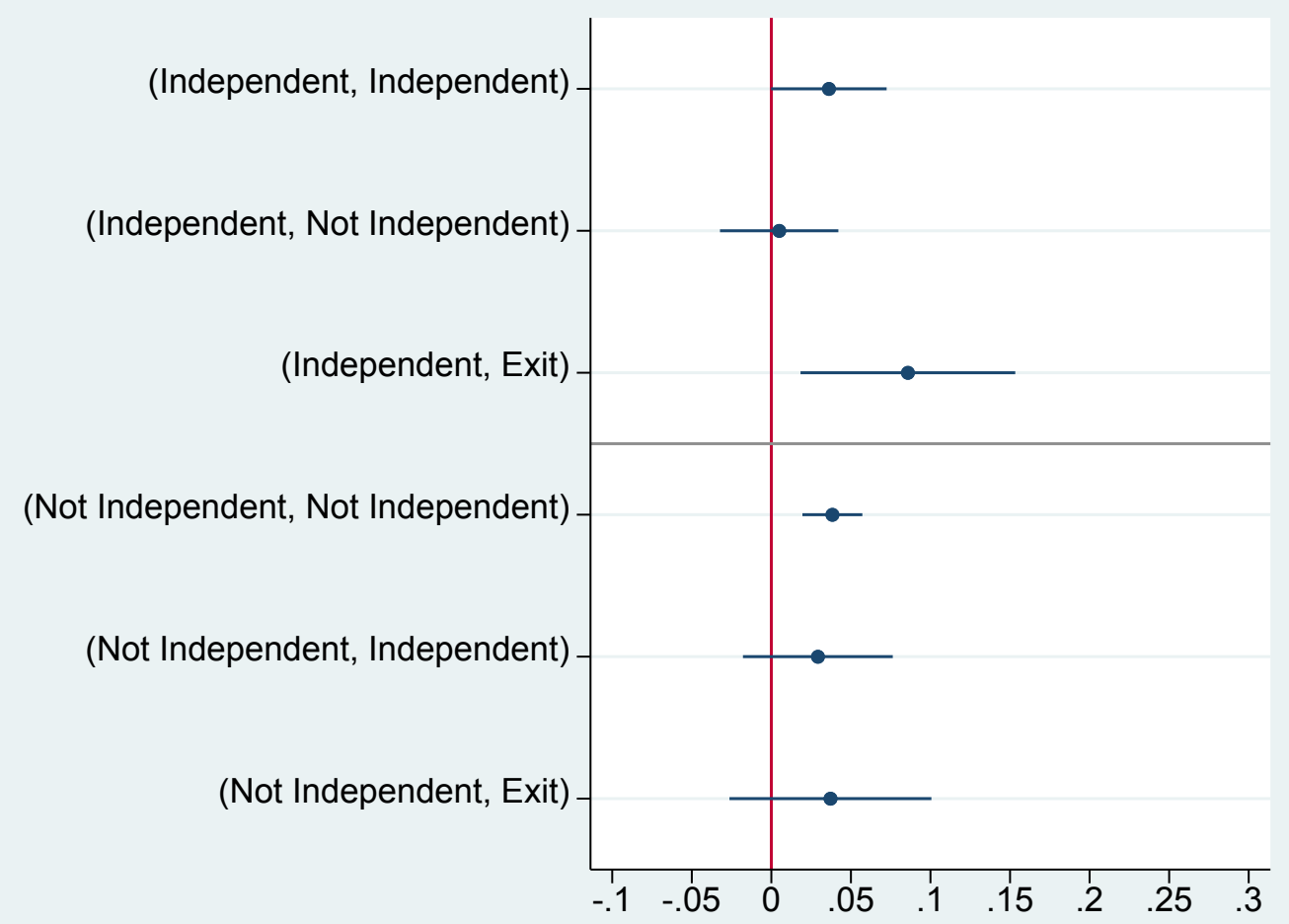


Figure 5. Willingness to pay for training opportunities

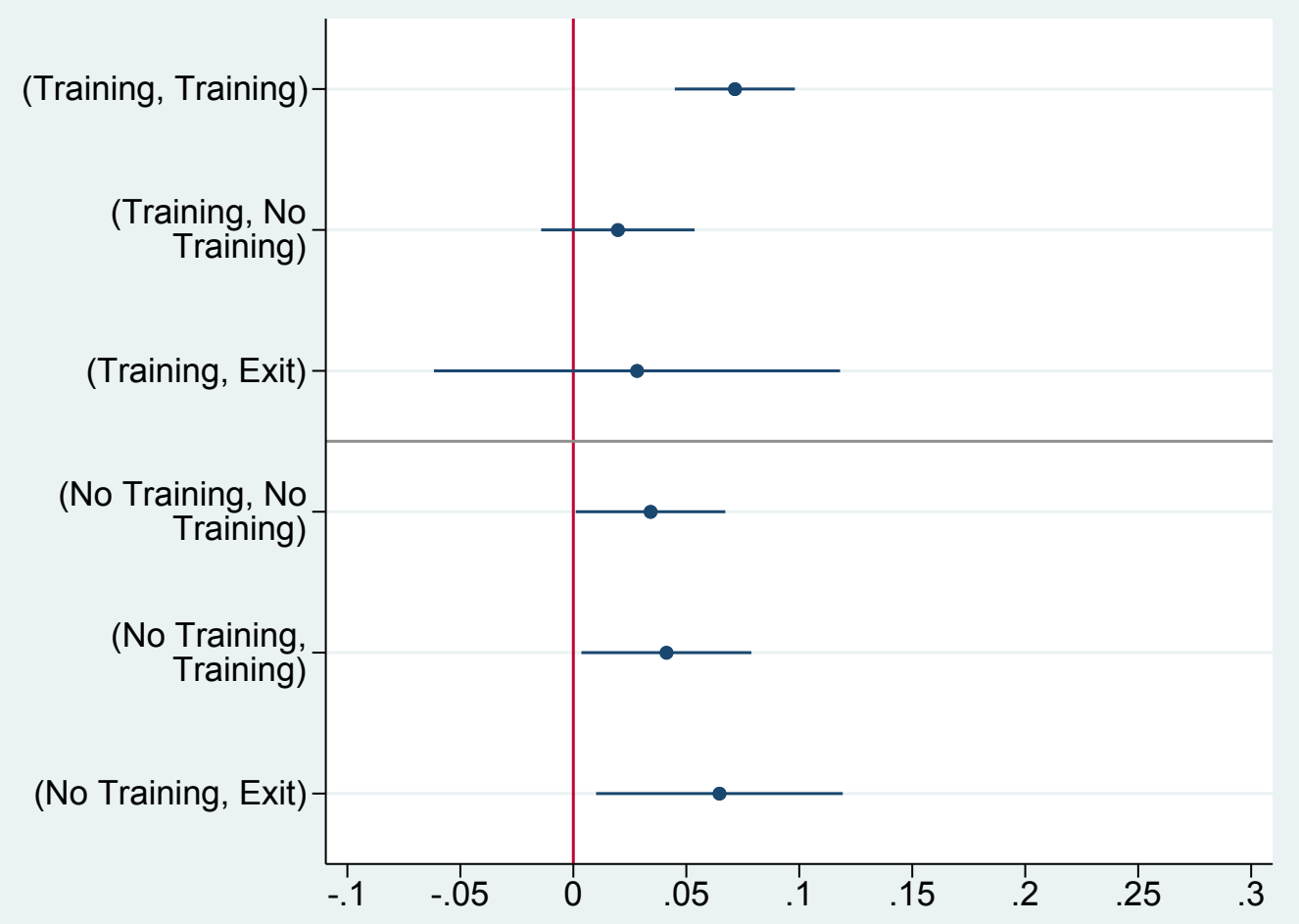


Figure 6. Willingness to pay for frequent (vs. occasional) opportunities to serve community

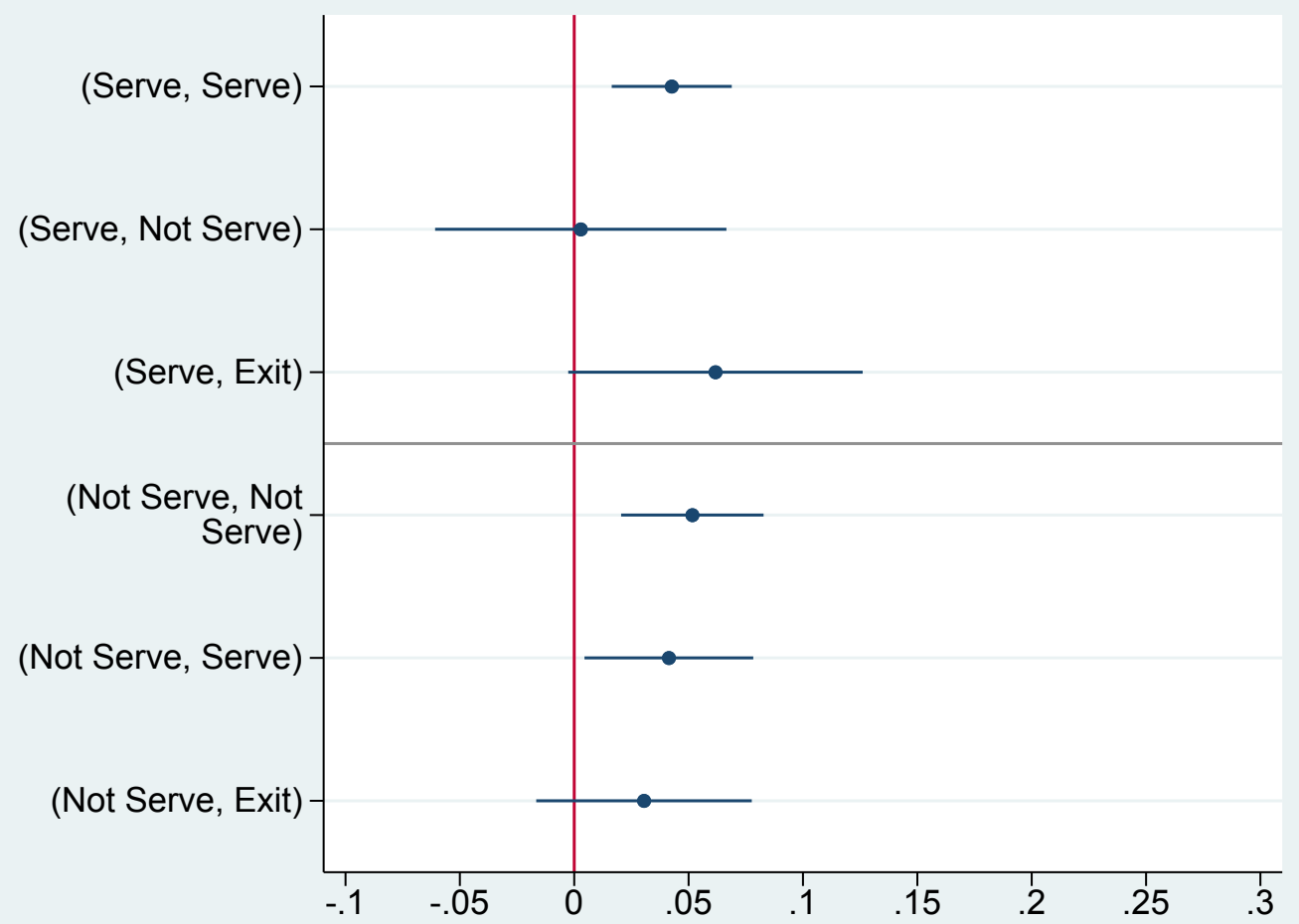


Figure 7. Willingness to pay for job characteristics by below- vs. above-median self-reported probability of working at age 62, ages 50 to 61

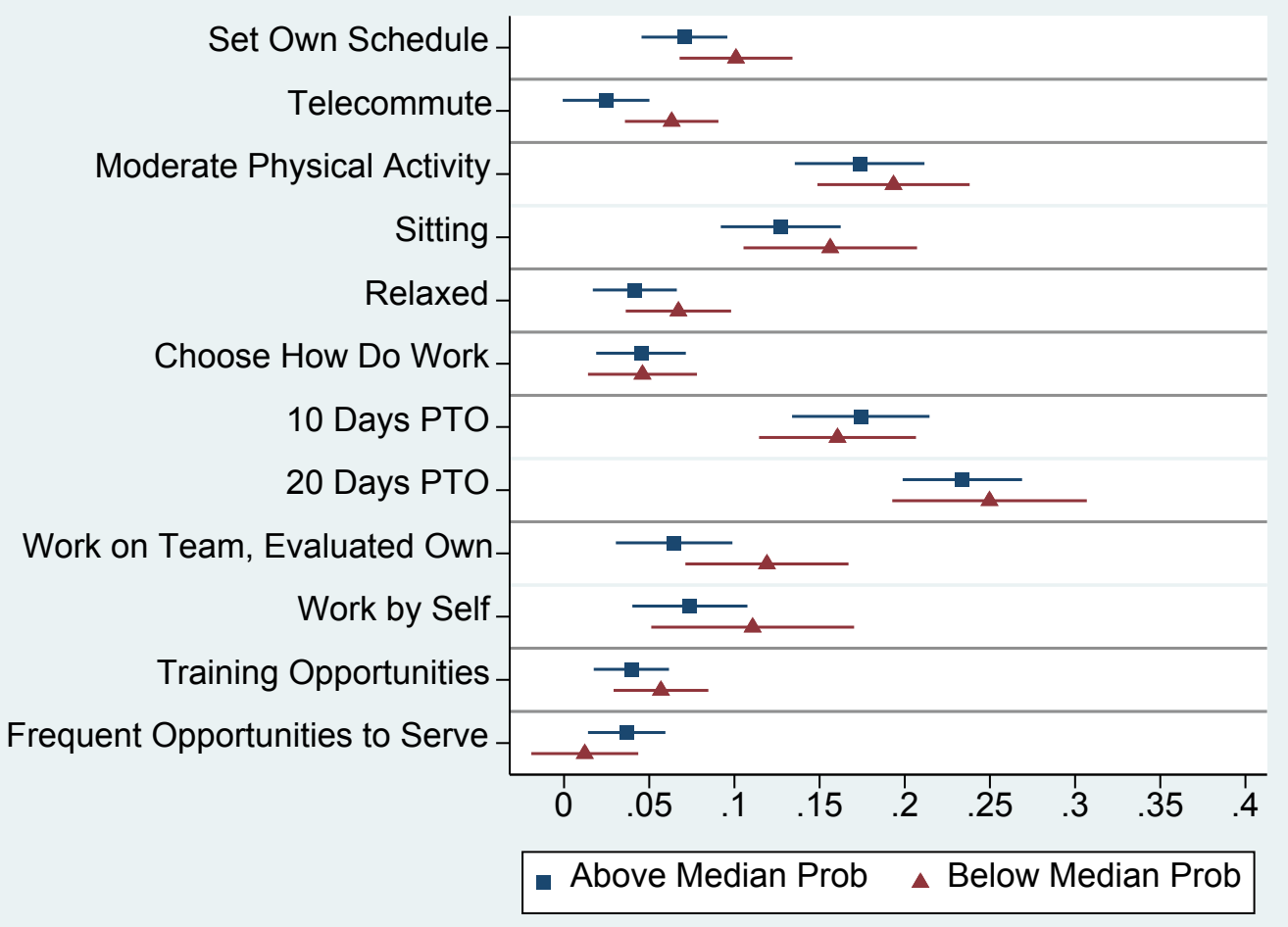


Figure 8. Willingness to pay for job characteristics by current work status, ages 62+

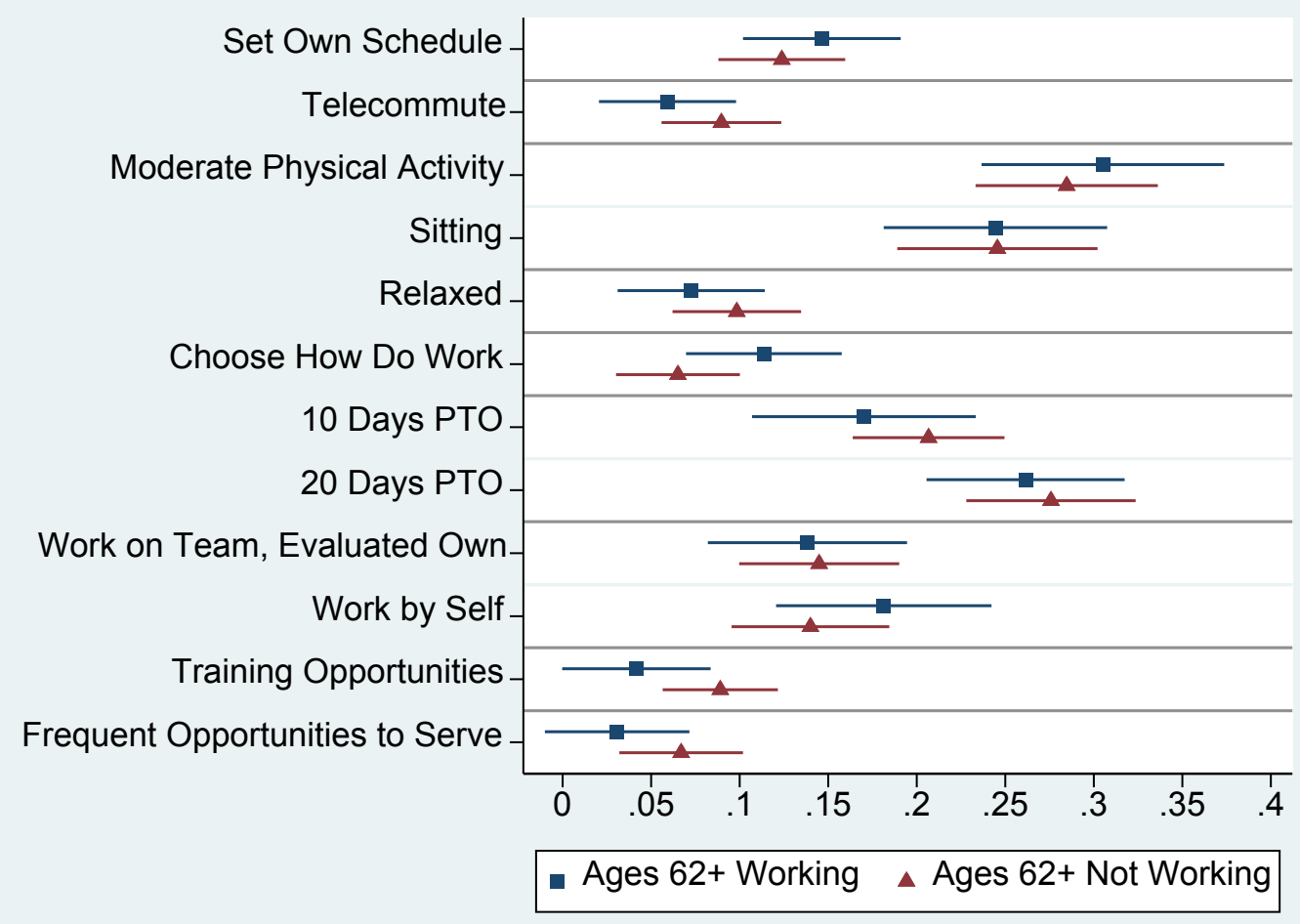


Table 1. Crosswalk between attributes in stated preference choice experiments and AWCS

\begin{tabular}{|c|c|c|}
\hline Dimension & Attribute in SP Module & Definition in $A W C S$ \\
\hline \multirow[t]{2}{*}{$\begin{array}{l}\text { Control over } \\
\text { Hours }\end{array}$} & Set your own schedule & $\begin{array}{l}\text { Q39: My working hours are entirely determined by me; } \\
\text { or, I can adapt my working hours within certain limits }\end{array}$ \\
\hline & Schedule is set by manager & $\begin{array}{l}\text { Q39: I can choose between several fixed working } \\
\text { schedules determined by my company/organization; or, } \\
\text { My working time arrangements are set by the } \\
\text { company/organization with no possibility for changes }\end{array}$ \\
\hline \multirow[t]{2}{*}{$\begin{array}{l}\text { Option to } \\
\text { Telecommute }\end{array}$} & Yes & $\begin{array}{l}\text { N8: Can choose where you work during regular } \\
\text { business hours }\end{array}$ \\
\hline & No & $\begin{array}{l}\text { N8: Can not choose where you work during regular } \\
\text { business hours }\end{array}$ \\
\hline \multirow[t]{2}{*}{ Pace } & Relaxed & $\begin{array}{l}\text { Q45a: Working at very high speed... around } 1 / 4 \text { of the } \\
\text { time, almost never or never }\end{array}$ \\
\hline & Fast-paced & $\begin{array}{l}\text { Q45a: Working at very high speed... around half of the } \\
\text { time, around } 3 / 4 \text { of the time, almost all of the time, or all } \\
\text { of the time }\end{array}$ \\
\hline \multirow[t]{2}{*}{ Independence } & $\begin{array}{l}\text { You can choose how you do } \\
\text { your work }\end{array}$ & Q50b: Able to choose or change methods of work \\
\hline & $\begin{array}{l}\text { Your tasks and procedures } \\
\text { are well-defined }\end{array}$ & Q50b: Not able to choose or change methods of work \\
\hline \multirow[t]{2}{*}{ Training } & $\begin{array}{l}\text { You have the skills for this } \\
\text { job and there are } \\
\text { opportunities to gain } \\
\text { valuable new skills }\end{array}$ & $\begin{array}{l}\text { Q61: Over the past } 12 \text { months, have undergone on-the- } \\
\text { job training to improve your skills }\end{array}$ \\
\hline & $\begin{array}{l}\text { You have the skills for this } \\
\text { job }\end{array}$ & $\begin{array}{l}\text { Q61: Over the past } 12 \text { months, have not undergone on- } \\
\text { the-job training to improve your skills }\end{array}$ \\
\hline \multirow[t]{2}{*}{$\begin{array}{l}\text { Impact on } \\
\text { Society }\end{array}$} & $\begin{array}{l}\text { Frequent opportunities to } \\
\text { make a positive impact on } \\
\text { your community or society }\end{array}$ & $\begin{array}{l}\text { N3b: Your work provides you with [the opportunity to] } \\
\text { make positive impact on community/society...most of } \\
\text { the time, or always }\end{array}$ \\
\hline & $\begin{array}{l}\text { Occasional opportunities to } \\
\text { make a positive impact on } \\
\text { your community or society }\end{array}$ & $\begin{array}{l}\text { N3b: Your work provides you with [the opportunity to] } \\
\text { make positive impact on } \\
\text { community/society...sometimes, rarely, or never }\end{array}$ \\
\hline
\end{tabular}


Table 2. Summary statistics on job transitions, 2015 to 2018

\begin{tabular}{|c|c|c|c|c|c|c|c|c|c|}
\hline \multirow[b]{2}{*}{ Attribute } & \multirow[b]{2}{*}{ Statistic } & \multicolumn{4}{|c|}{ Has Attribute in Period 1} & \multicolumn{4}{|c|}{ Lacks Attribute in Period 1} \\
\hline & & Subtotal & $\begin{array}{c}\text { Has in } \\
\text { Period } 2\end{array}$ & $\begin{array}{l}\text { Lacks in } \\
\text { Period } 2\end{array}$ & $\begin{array}{c}\text { Exit in } \\
\text { Period } 2\end{array}$ & Subtotal & $\begin{array}{l}\text { Lacks in } \\
\text { Period } 2\end{array}$ & $\begin{array}{c}\text { Has in } \\
\text { Period } 2\end{array}$ & $\begin{array}{c}\text { Exit in } \\
\text { Period } 2\end{array}$ \\
\hline \multirow[t]{2}{*}{ Control over Hours } & Unweighted N & 545 & 321 & 137 & 87 & 681 & 459 & 123 & 99 \\
\hline & Weighted \% & $53.0 \%$ & $38.5 \%$ & $9.6 \%$ & $4.8 \%$ & $47.0 \%$ & $30.0 \%$ & $11.1 \%$ & $6.0 \%$ \\
\hline \multirow[t]{2}{*}{ Option to Telecommute } & Unweighted $\mathrm{N}$ & 289 & 167 & 82 & 40 & 937 & 676 & 115 & 146 \\
\hline & Weighted \% & $22.2 \%$ & $12.9 \%$ & $7.1 \%$ & $2.1 \%$ & $77.8 \%$ & $59.7 \%$ & $9.4 \%$ & $8.7 \%$ \\
\hline \multirow[t]{2}{*}{ Relaxed Pace } & Unweighted N & 434 & 236 & 126 & 72 & 792 & 518 & 160 & 114 \\
\hline & Weighted \% & $31.9 \%$ & $17.5 \%$ & $10.0 \%$ & $4.4 \%$ & $68.1 \%$ & $48.9 \%$ & $12.8 \%$ & $6.4 \%$ \\
\hline \multirow[t]{2}{*}{ Independence } & Unweighted N & 323 & 116 & 154 & 53 & 903 & 667 & 103 & 133 \\
\hline & Weighted \% & $26.6 \%$ & $9.7 \%$ & $14.0 \%$ & $2.9 \%$ & $73.4 \%$ & $56.4 \%$ & $9.0 \%$ & $7.9 \%$ \\
\hline \multirow[t]{2}{*}{ Training Opportunities } & Unweighted N & 718 & 474 & 155 & 89 & 508 & 249 & 162 & 97 \\
\hline & Weighted \% & $61.8 \%$ & $43.4 \%$ & $13.8 \%$ & $4.6 \%$ & $38.2 \%$ & $18.2 \%$ & $13.8 \%$ & $6.2 \%$ \\
\hline \multirow[t]{2}{*}{ Impact on Society } & Unweighted N & 652 & 403 & 162 & 87 & 574 & 319 & 156 & 99 \\
\hline & Weighted \% & $50.8 \%$ & $30.9 \%$ & $15.0 \%$ & $4.9 \%$ & $49.2 \%$ & $29.2 \%$ & $14.1 \%$ & $5.9 \%$ \\
\hline
\end{tabular}

Note: Sample consists of workers ages 25 to 71 in 2015 . "Exit in Period 2" denotes those not working in 2018. 
Table 3. Estimates of willingness to pay for each attribute by transition group

\begin{tabular}{|l|c|ccc|c|ccc|}
\hline & \multicolumn{3}{|c|}{ Has Attribute in Period 1 } & \multicolumn{3}{c|}{ Lacks Attribute in Period 1 } \\
\cline { 2 - 9 } & Subtotal & $\begin{array}{c}\text { Has in } \\
\text { Period 2 }\end{array}$ & $\begin{array}{c}\text { Lacks in } \\
\text { Period 2 }\end{array}$ & $\begin{array}{c}\text { Exit in } \\
\text { Period 2 }\end{array}$ & Subtotal & $\begin{array}{c}\text { Lacks in } \\
\text { Period 2 }\end{array}$ & $\begin{array}{c}\text { Has in } \\
\text { Period 2 }\end{array}$ & $\begin{array}{c}\text { Exit in } \\
\text { Period 2 }\end{array}$ \\
\cline { 2 - 10 } Attribute & $\mathbf{( A )}$ & $\mathbf{( A 1 )}$ & $\mathbf{( A 2 )}$ & $\mathbf{( A 3 )}$ & $\mathbf{( B )}$ & $\mathbf{( B 1 )}$ & $\mathbf{( B 2 )}$ & $\mathbf{( B 3 )}$ \\
\hline Control over Hours & 0.107 & 0.111 & 0.086 & 0.126 & $0.048^{* * *}$ & 0.033 & $0.072^{*}$ & $0.078^{*}$ \\
& $(0.009)$ & $(0.011)$ & $(0.021)$ & $(0.022)$ & $(0.011)$ & $(0.014)$ & $(0.023)$ & $(0.028)$ \\
\hline Option to Telecommute & 0.072 & 0.098 & $0.046^{* *}$ & $0.012^{*}$ & $0.034^{* *}$ & 0.032 & 0.039 & 0.045 \\
& $(0.015)$ & $(0.019)$ & $(0.023)$ & $(0.055)$ & $(0.010)$ & $(0.013)$ & $(0.025)$ & $(0.022)$ \\
\hline Relaxed Pace & 0.062 & 0.085 & $0.013^{* * *}$ & 0.074 & $0.033^{*}$ & 0.023 & $0.059^{*}$ & 0.052 \\
& $(0.015)$ & $(0.020)$ & $(0.024)$ & $(0.028)$ & $(0.010)$ & $(0.012)$ & $(0.021)$ & $(0.025)$ \\
\hline Independence & 0.027 & 0.036 & 0.005 & 0.086 & 0.038 & 0.038 & 0.029 & 0.037 \\
& $(0.013)$ & $(0.019)$ & $(0.019)$ & $(0.034)$ & $(0.009)$ & $(0.010)$ & $(0.024)$ & $(0.032)$ \\
\hline Training Opportunities & 0.058 & 0.071 & $0.020^{* *}$ & 0.028 & 0.042 & 0.034 & 0.041 & 0.064 \\
& $(0.011)$ & $(0.014)$ & $(0.017)$ & $(0.046)$ & $(0.012)$ & $(0.017)$ & $(0.019)$ & $(0.028)$ \\
\hline Impact on Society & 0.032 & 0.043 & 0.003 & 0.062 & 0.046 & 0.052 & 0.041 & 0.030 \\
& $(0.013)$ & $(0.013)$ & $(0.032)$ & $(0.033)$ & $(0.011)$ & $(0.016)$ & $(0.019)$ & $(0.024)$ \\
\hline
\end{tabular}


Table 4. Estimates of willingness to pay for each attribute by age group and (expected) retirement

\begin{tabular}{|c|c|c|c|c|c|c|}
\hline \multirow[b]{2}{*}{ Attribute } & \multicolumn{3}{|c|}{ Ages 50 to 61} & \multicolumn{3}{|c|}{ Ages 62+ } \\
\hline & Low Prob & High Prob & P-Value & Not Working & Working & P-Value \\
\hline Control over Hours & $\begin{array}{c}0.101 * * * \\
(0.017)\end{array}$ & $\begin{array}{c}0.071 * * * \\
(0.013)\end{array}$ & 0.155 & $\begin{array}{c}0.124 * * * \\
(0.018)\end{array}$ & $\begin{array}{c}0.146 * * * \\
(0.023)\end{array}$ & 0.438 \\
\hline Option to Telecommute & $\begin{array}{c}0.063 * * * \\
(0.014)\end{array}$ & $\begin{array}{l}0.025^{*} \\
(0.013)\end{array}$ & 0.044 & $\begin{array}{c}0.090^{* * *} \\
(0.017)\end{array}$ & $\begin{array}{c}0.059 * * * \\
(0.020)\end{array}$ & 0.245 \\
\hline Moderate Physical Activity & $\begin{array}{c}0.193 * * * \\
(0.023)\end{array}$ & $\begin{array}{c}0.174 * * * \\
(0.019)\end{array}$ & 0.507 & $\begin{array}{c}0.285 * * * \\
(0.026)\end{array}$ & $\begin{array}{c}0.305^{* * *} \\
(0.035)\end{array}$ & 0.64 \\
\hline Sitting & $\begin{array}{c}0.156^{* * *} \\
(0.026)\end{array}$ & $\begin{array}{c}0.127 * * * \\
(0.018)\end{array}$ & 0.358 & $\begin{array}{c}0.246 * * * \\
(0.029)\end{array}$ & $\begin{array}{c}0.244 * * * \\
(0.032)\end{array}$ & 0.979 \\
\hline Relaxed Pace & $\begin{array}{c}0.067 * * * \\
(0.016)\end{array}$ & $\begin{array}{c}0.042 * * * \\
(0.013)\end{array}$ & 0.205 & $\begin{array}{c}0.098 * * * \\
(0.019)\end{array}$ & $\begin{array}{c}0.073 * * * \\
(0.021)\end{array}$ & 0.362 \\
\hline Independence & $\begin{array}{c}0.046 * * * \\
(0.016)\end{array}$ & $\begin{array}{c}0.045^{* * *} \\
(0.013)\end{array}$ & 0.967 & $\begin{array}{c}0.065^{* * *} \\
(0.018)\end{array}$ & $\begin{array}{c}0.114 * * * \\
(0.022)\end{array}$ & 0.09 \\
\hline 10 days PTO & $\begin{array}{c}0.161 * * * \\
(0.023)\end{array}$ & $\begin{array}{c}0.174 * * * \\
(0.021)\end{array}$ & 0.662 & $\begin{array}{c}0.207 * * * \\
(0.022)\end{array}$ & $\begin{array}{c}0.170^{* * *} \\
(0.032)\end{array}$ & 0.348 \\
\hline 20 days PTO & $\begin{array}{c}0.250 * * * \\
(0.029)\end{array}$ & $\begin{array}{c}0.234 * * * \\
(0.018)\end{array}$ & 0.641 & $\begin{array}{c}0.276 * * * \\
(0.024)\end{array}$ & $\begin{array}{c}0.261 * * * \\
(0.029)\end{array}$ & 0.702 \\
\hline Team-Based, Own Evaluation & $\begin{array}{c}0.119 * * * \\
(0.024)\end{array}$ & $\begin{array}{c}0.065 * * * \\
(0.017)\end{array}$ & 0.069 & $\begin{array}{c}0.145^{* * *} \\
(0.023)\end{array}$ & $\begin{array}{c}0.138 * * * \\
(0.029)\end{array}$ & 0.858 \\
\hline Work by Self & $\begin{array}{c}0.111 * * * \\
(0.030)\end{array}$ & $\begin{array}{c}0.074 * * * \\
(0.017)\end{array}$ & 0.292 & $\begin{array}{c}0.140 * * * \\
(0.023)\end{array}$ & $\begin{array}{c}0.181 * * * \\
(0.031)\end{array}$ & 0.282 \\
\hline Training Opportunities & $\begin{array}{c}0.057 * * * \\
(0.014)\end{array}$ & $\begin{array}{c}0.040 * * * \\
(0.011)\end{array}$ & 0.338 & $\begin{array}{c}0.089 * * * \\
(0.017)\end{array}$ & $\begin{array}{l}0.042 * \\
(0.021)\end{array}$ & 0.08 \\
\hline Impact on Society & $\begin{array}{c}0.012 \\
(0.016)\end{array}$ & $\begin{array}{c}0.037 * * * \\
(0.012)\end{array}$ & 0.212 & $\begin{array}{c}0.067 * * * \\
(0.018)\end{array}$ & $\begin{array}{c}0.031 \\
(0.021)\end{array}$ & 0.187 \\
\hline Best vs. Worst Job, All Attributes & $\begin{array}{c}0.628 * * * \\
(0.040)\end{array}$ & $\begin{array}{c}0.550 * * * \\
(0.026)\end{array}$ & 0.103 & $\begin{array}{c}0.747 * * * \\
(0.026)\end{array}$ & $\begin{array}{c}0.742 * * * \\
(0.033)\end{array}$ & 0.916 \\
\hline $\mathbf{N}$ & 329 & 353 & & 442 & 275 & \\
\hline
\end{tabular}

Notes: Stars denote statistical significance from zero at the following levels: * $10 \%, * * 5 \%, * * * 1 \%$. P-values shown for tests of statistically significant differences between low- and high-probability (of working at age 62) workers ages 50 to 61 and between working versus nonworking individuals ages $62+$, respectively. 